\title{
IN SEARCH OF THE PEACE DIVIDEND
}

The sense of relief that greeted the end of the cold war was soon joined by an eager anticipation of the peace dividend, an economic rebate after years of massive military spending. In the event the relief was palpable but the economic impact was shortlived. While world military expenditure in 2004 was still six per cent below the 1988 cold war peak, this has to be balanced against an average annual rate of increase over the past six years of 4.2 per cent in real terms. In the three years to 2004 , this figure bounced up to six per cent.

The major contributor to the escalation is the US budget for the 'global war on terrorism', primarily for operations in Afghanistan and Iraq, although the latter had no demonstrable link to terrorism. The money has come largely from supplementary appropriations on top of the regular defence budget. In 2003-05, these amounted to $\$ 238$ billion, more than the combined military spending in 2004 of the entire developing world, including China and the Middle East.

But developing countries have also increased their military spending, even more than official figures suggest, often to finance internecine warfare. Low national income and violent conflict seem to go together since eight out of ten of the world's poorest countries are suffering or have recently suffered from large-scale armed conflict. ${ }^{1}$

The costs are hard to pin down. Governments engaged in civil war tend to play down military expenditure, which, in any case, does not take account of spending by non-government forces, often financed from the sale of natural resources. Moreover, the cost of fighting is only part of the total cost of war. Also to be taken into account, though difficult to quantify, is the impact on economic growth both on the country at war and on neighbouring countries that have nothing to do with the conflict.

Put like this it might seem that a sustainable peace dividend will remain beyond our grasp. But though not immediately apparent, there are grounds for optimism. Knowledge is increasingly emerging about the root causes of civil conflict starting with political, economic and social inequalities, extreme poverty, economic stagnation, poor government services, high unemployment and environmental degradation. ${ }^{2}$ While some strategists call for the adoption of 'co-operative imperialism' which implies active military intervention in the affairs of developing countries by major powers, others argue that a long-term remedy requires an integrated policy on security and development, including new types of economic aid programmes, debt cancellation, the removal of barriers to trade in goods and services from low income countries and the sharing of technological know-how, some of which could be financed through a reallocation of resources from military to civil means of promoting peace and security.

This debate overlaps with the war on terrorism. The first official US reaction to the events of September 11, 2001 was to boost military spending and to spend more on internal security with increases in police manpower, more sophisticated intelligence services and tighter border controls. While these moves addressed the symptoms of terrorism, governments are aware of the need to address also the causes of terrorism. The National Strategy for Combating Terrorism, adopted by the USA in February 2003, specifies long-term measures against the 'underlying conditions that promote the despair and the destructive visions of political change that lead people to embrace, rather than shun, terrorism'.

Yet the USA still gives priority to military expenditure of a sort that could only be justified if a continental war was in prospect. Furthermore, the war on terrorism has also had a strong domestic impact in the USA. The Patriot Act, introduced after the attacks of September 11,2001, sliced into civil liberties with powers for law enforcement agencies to use wire taps, search warrants and other surveillance techniques, often under the cloak of secrecy. That these radical changes to the US legal system were introduced with little in the way of public debate or protest is a measure of the widespread fear in the USA of what terrorists might achieve if they get their hands on high-tech weapons. But little has been done to help towards eradicating the breeding grounds of violence.

European countries spend less on the military but also give emphasis to internal security with wider powers to the police to hold suspects without trial, seemingly unaware that they risk the erosion of civil liberties and the alienation of minority groups whose co-operation is crucial to the success of counterterrorism.

All the evidence suggests that there will belittle progress towards lifting the threat of terrorism until resources are reallocated from military build-up and ever more onerous domestic security in the richer nations to helping poorer countries achieve social cohesion, political stability and economic development. Policies to these ends might even produce the elusive peace dividend.

This is the thinking behind the concept of 'global public goods', embraced by the United Nations Development Programme. ${ }^{3}$ At the national level, public goods, such as health, education and defence, are paid for, not by the individual citizen but by community-wide taxes. Similarly, global public goods-measures to promote peace and security-should be raised above individual countries to become world concerns. This may seem an obvious point but it has failed to make the required impact on developed countries. In fact, net resource flows from member countries of the OECD to countries in need of aid fell from $\$ 264$ billion in 1995 to $\$ 151$ billion in 2002. A World Bank study estimates that another \$40-60 billion a year in foreign aid is required to reach the UN's Millennium Development Goals by $2015 .{ }^{4}$ Broader policies to provide for poor countries and fragile states would require substantially more resources.

How is the necessary money to be raised? Various forms of global taxes have been suggested. In the 1980s, the Brandt Commission put forward the idea of imposing taxes on international trade, notably the arms trade, for development purposes. Grants from private foundations and other nongovernment organizations have increased in recent years. At the time of writing, Bill Gates has backed a health foundation for the developing world to the tune of $\$ 29$ billion. However, national governments are notoriously slow to get the point. The best laid plans are liable to be disrupted by short-sighted politicians in pursuit of votes. Yet in an increasingly interdependent world the international financing of peace and security on an unprededented scale is a matter of urgency. We should not wait for another terrorist outrage to spur action.

Elisabeth Sköns (Stockholm International Peace Research Institute)

${ }^{1}$ F. Stewart. Root causes of violent conflict in developing countries. British Medical Journal, vol. 324, 9 Feb. 2002; p. 342

${ }^{2}$ F. Stewart and V. FitzGerald (eds.) War and Underdevelopment, vol. 1, The Economic and Social Consequences of Conflict, OUP, 2001. (See also the UN's High Level Panel Report: http://www.un.org/ secureworld/)

${ }^{3}$ I. Kaul et al, Providing Global Public Goods: Managing Globalization. UN Development Programme, OUP, 2003

${ }^{4}$ World Bank. The costs of attaining the Millennium Development Goals 